\title{
Clinical Trials of Rhodiola rosea in Tomsk in the Late Soviet Period
}

\author{
P. A. Vasilyev, O. I.Zvonareva, A. N. Petrenko
}

For citation: Vasilyev P. A., Zvonareva O.I., Petrenko A. N. Clinical Trials of Rhodiola rosea in Tomsk in the Late Soviet Period. Vestnik of Saint Petersburg University. History, 2020, vol. 65, issue 3, pp. 814825. https://doi.org/10.21638/11701/spbu02.2020.307

Rhodiola rosea is a Siberian medicinal plant possessing qualities of a central nervous system stimulant that has been traditionally used in the folk medicine of the indigenous peoples in Siberia. Between the 1960s and the 1980s, the plant had been intensively studied in the scientific laboratories of Tomsk. The study of physicochemical properties of the plant and its effects on humans was initially carried out in the Tomsk Medical Institute (TMI) by a large research group headed by A.S. Saratikov and E. A. Krasnov. Following a series of animal studies in the early 1960s, Saratikov started to enlist human volunteers from TMI students and stuff and examine the effects of the plant on concentration and auto-suggestion. These trials were later expanded, and a number of medical institutions in Tomsk incorporated them into their research programs, seemingly hailing Rhodiola rosea as a potential all-curing miracle drug for the overworked and stressed modern self. (Interestingly enough, there has recently been a renewed interest in the plant in the West that has corroborated a number of Soviet findings). At the same time, research into the history of Rhodiola rosea trials also highlights both numerous ethically problematic issues in the treatment of research participants as well as unexpected divergences from the officially prescribed Soviet clinical trials practices. Using examples from a large number of published scientific studies and corroborating them with materials from

Pavel A. Vasilyev - PhD in History, Senior Lecturer, National Research University Higher School of Economics, 17, Promyshlennaia ul., St. Petersburg, 198099, Russian Federation; pvasilev@hse.ru

Павел Андреевич Васильев - канд. ист. наук, ст. преп., Национальный исследовательский университет «Высшая школа экономики», Российская Федерация, 198099, Санкт-Петербург, Промышленная ул., 17; pvasilev@hse.ru

Olga I.Zvonareva - PhD, Assistant Professor, Maastricht University, 616, Postbus, MD Maastricht, 6200, The Netherlands; o.zvonareva@maastrichtuniversity.nl

Ольга Игоревна Звонарева - PhD, ст. преп., Университет Маастрихта, Нидерланды, 6200 MD, Маастрихт, ул. Постбас, 616; o.zvonareva@maastrichtuniversity.nl

Alexander N.Petrenko - PhD in History, Senior Lecturer, Siberian State Medical University, 2, Moskovskii trakt, Tomsk, 634050, Russian Federation; alexandr_n@mail.ru

Александр Николаевич Петренко - канд. ист. наук, ст. преп., Сибирский государственный медицинский университет, Российская Федерация, 634050, Томск, Московский тракт, 2; alexandr_n@mail.ru

Funded by the Russian Science Foundation (grant no. 18-78-10016, "Balancing knowledge reliability and ethical acceptability in clinical trials: from emergence of a randomized controlled trial to precision medicine").

Исследование выполнено за счет гранта Российского научного фонда (проект № 18-78-10016, «Между надежностью знаний и этической приемлемостью практик их получения: прошлое и настоящее клинических исследований лекарственных средств»).

() Санкт-Петербургский государственный университет, 2020 
oral history interviews with researchers and study participants, this paper explores the local idiosyncrasies that shaped Soviet clinical trials on the ground.

Keywords: Rhodiola rosea, A. S. Saratikov, Tomsk pharmacological research school, History of medicine in Tomsk, Bioethics.

\title{
Клинические испытания родиолы розовой в Томске в позднесоветский период
}

\author{
П. А. Васильев, О. И.Звонарева, А. Н. Петренко
}

Для цитирования: Vasilyev P. A., Zvonareva O. I., Petrenko A. N. Clinical Trials of Rhodiola rosea in Tomsk in the Late Soviet Period // Вестник Санкт-Петербургского университета. История. 2020. Т.65. Вып. 3. С. 814-825. https://doi.org/10.21638/11701/spbu02.2020.307

Родиола розовая - это сибирское лекарственное растение, обладающее стимулирующим воздействием на центральную нервную систему человека. Растение традиционно использовалось в народной медицине коренных народов Сибири. В 1960-1980-х гг. свойства растения активно изучались в научных лабораториях Томска. Изучение физико-химических свойств растения и его воздействия на человека изначально проводилось в Томском медицинском институте большой группой ученых под руководством А.С. Саратикова и Е.А. Краснова. После ряда испытаний на животных в начале 1960-х гг, Саратиков начал рекрутировать добровольцев из числа студентов и сотрудников института, чтобы изучать способность человека к концентрации внимания и аутосуггестии на фоне приема препаратов родиолы. В дальнейшем испытания лекарственных средств были расширены и проводились в целом ряде медицинских учреждений Томска. Ученые видели в препаратах родиолы розовой универсальное терапевтическое средство, способное снять стресс и побороть усталость в любой ситуации (примечательно, что данные наблюдения вполне подтверждаются в ряде недавно опубликованных зарубежными учеными работ, которые продемонстрировали возрождение интереса к свойствам этого лекарственного растения). В контексте продолжавшейся холодной войны особый акцент делался на возможности применения данной группы препаратов в экстремальных условиях. В то же время изучение истории клинических испытаний родиолы розовой демонстрирует, что с этической точки зрения отношение к участникам испытаний было весьма спорным, а исследователи в своих изысканиях зачастую достаточно далеко уходили от официально одобренной линии. Используя многочисленные примеры из опубликованных научных работ, а также из мемуаров и воспоминаний ученых и участников испытаний, мы демонстрируем, каким образом глобальная повестка дня и локальный контекст определили историю клинических исследований в СССР в годы холодной войны.

Ключевые слова: родиола розовая, А. С. Саратиков, томская школа фармакологии, история медицины в Томске, биоэтика.

Introduction. Over the last 30 years the Russian pharmaceutical industry has practically adopted all of the foreign standards of drug development that evolved in the West (and, more specifically, in the USA) over the second half of the $20^{\text {th }}$ century. Among such standards, the most important is the international standard of "good clinical practice" (GCP) and related standards in the laboratory and manufacturing areas (GLP and GMP, respectively) that were introduced by the International Council for Harmonisation of Technical Requirements for Pharmaceuticals for Human Use (ICH). This process of adopting the new standards started after the collapse of the USSR, and over the course of 
the last few decades, the Soviet experience of organizing and regulating drug development has practically been forgotten. Only a few specialists who witnessed the Soviet period still remain in the various research, manufacturing and regulatory institutions in contemporary Russia.

Existing scholarship on the history of Soviet pharmaceutical regulation also provides only limited information regarding the development and testing of new drugs in the USSR $^{1}$. More specifically, it remains unclear how the decisions about designing, carrying out and implementing clinical trials of new pharmaceuticals were made once an experimental drug was deemed promising. With regards to ethics, very little is known about the processes of selecting participants in the trials, ensuring the voluntary character of their participation, soliciting informed consent, and upholding the standards of medical ethics (as relates, for example, to the use of placebo). This article seeks to fill some of these gaps by focusing on the specific example of Tomsk scientific school of pharmacology and its involvement in clinical trials of Rhodiola rosea in the late Soviet period.

Studying medicinal plants in Tomsk. Often, scientific groups based in more peripheral regions face problems in finding good research topics due to inadequate state of research facilities, logistical issues, lack of financial resources, and more generally - difficulties in competing with larger research communities in metropolitan areas. The Tomsk pharmacology school found a solution to this problem by actively utilizing local Siberian flora in their research ${ }^{2}$. For example, in the 1930s, a prominent Tomsk scientist and head of the Pharmacology Department of Tomsk Medical Institute (TMI) Nikolai V. Vershinin, described a new way to produce camphor (commonly applied topical medication at the time) from the boughs of Siberian fir ${ }^{3}$. This discovery proved to be of vital importance for many wounded soldiers during the Second World War as the Soviet Union was unable to purchase natural camphor from Japan at the moment ${ }^{4}$.

The role of local pharmaceutical resources increased greatly after the Nazi invasion of the Soviet Union in June 1941. Over the next years, Tomsk became a large center for wounded soldiers and hosted several dozen evacuated hospitals 5 . However, difficult wartime conditions resulted in the severe lack of drugs as vast industrially developed territories in the European part of the Soviet Union were occupied by the German army, and international pharmaceutical ties got severed. Faced with such dire prospects, Tomsk scientists decided to extensively utilize local resources to provide medications for the wounded. Over the course of the 1940s, they offered numerous new approaches and medicine to compensate for the lack of standard drugs.

${ }^{1}$ For a classic Soviet overview, see: Babayan E. A., Utkin O. B. Osnovnye polozheniia aprobatsii lekarstvennykh sredstv v SSSR i zarubezhnykh stranakh. Moscow, 1982. - For a more recent perspective, see: Lepakhin V. K., Olefir Iu. V., Merkulov V. A., Buniatian N. D., Romanov B. K., Iavorskii A. N., Rychikhina E. M. Istoriia sozdaniia i razvitiia kontrol'no-razreshitel'noi sistemy v Rossii (25 let so vremeni sozdaniia pervogo gosudarstvennogo uchrezhdeniia po ekspertnoi otsenke lekarstvennykh sredstv) // Vedomosti Nauchnogo tsentra ekspertizy sredstv meditsinskogo primeneniia. 2016. Iss. 2. P.3-10.

2 Vengerovskii A.I. Stareishaia kafedra farmakologii v Sibiri (120 let so dnia otkrytiia) // Biulleten' sibirskoi meditsiny. 2011. Iss. 5. P.17-24; Vengerovskii A.I. Pervaia kafedra farmakologii Sibiri // Eksperimental'naia i klinicheskaia farmakologiia. 2008. Iss. 2. P. 60-64.

3 Vengerovskii A.I., Vaizova O.E., Plotnikova T.M. Akademik Nikolai Vasil'evich Vershinin. Tomsk, 2017.

4 Saratikov A.S. Kamfora. Tomsk, 1966. P.6.

${ }^{5}$ Karpov R.S. Vospominaniia ob uchitele (k 120-letiiu so dnia rozhdeniia akademika AMN SSSR D. D. Iablokova) // Biulleten' sibirskoi meditsiny. 2016. Iss. 5. P. 189. 
Wartime conditions demanded extraordinary measures, and, as our analysis of memoir literature shows, self-experimentation was quite common during this period. For example, this is how Professor Dmitrii D. Iablokov recalled his experience with testing an intravenous injection drug called sirenid: "I lied down on a couch; a nurse would give me an intravenous injection of the drug that had been received from Nikolai Vasilevich [Vershinin]. I tried to follow closely the beating of my heart. Never did I have any adverse reaction. Straight afterwards the new drug was administered to the wounded soldiers. There simply was no other solution"6. Clearly, the results of such an experiment alone were deemed legitimate evidence for further treatment of wounded soldiers with the drug.

Crucially, as sirenid, erizid and numerous other drugs were produced from local Siberian medicinal plants, they were deemed pharmaceutical success stories and important scientific discoveries. Professor Vershinin had further developed this study by exploring the properties of medicinal plants such as yellow foxglove, thermopsis, Jacob's ladder, rattlesnake root, everlasting pea, motherwort, Baikal skullcap, tansy, hare's ear, burnet, bergenia and snakeweed, among others. After Vershinin's death in 1951, this direction of research was continued by his former students Evgeniia M. Dumenova ${ }^{7}$ and Al'bert S. Saratikov who succeeded Vershinin as Heads of the Pharmacology Department (their tenures lasted in 1951-1970 and 1970-2002, respectively).

However, as the Soviet economy and science recovered from the Second World War, Tomsk pharmacologists had to further develop their research agenda and to look for new directions. By the 1960s, in the context of the Cold War as a global ideological (and potentially military) conflict and continuing Soviet concerns over increasing the productivity of their citizens, scientific study of the stimulants of the central nervous system and the socalled "adaptogenes" (drugs designed to increase the human ability to withstand adverse external conditions) became a highly attractive research area.

At that point, drugs made from plants such as gingseng, may chang or eleuterococcus had been used for a long time. But all of them had their issues - lack of raw materials; difficulty in cultivating them on the territory of USSR; weak or only transient therapeutical effect. Finally, in 1961, an expedition of Tomsk botanists in the mountainous regions of Altai discovered Rhodiola rosea, also known by indigenous peoples as "golden root". This plant turned out to be the subject of a whole series of studies that was unprecedented in terms of its length and the number of experiments conducted.

Discovering Rhodiola rosea. As mentioned, the scientific "discovery" of Rhodiola rosea was preceded by its active use in traditional Siberian medicine since times immemorial. Researchers have explained this seeming contradiction by the fact that indigenous population of Altai tried to limit the access of Russian colonists to the areas where the plant was widespread and did not share their vernacular knowledge on its medicinal properties beyond the most immediate family circle ${ }^{8}$. As a result, the special expedition that was launched by the Soviets already in 1934 failed to discover the legendary "golden root" as the scientists did not have access to local informants. The success of the 1961 expedition of the Biological Institute of the Siberian Branch of the Soviet Academy of Sciences was

${ }^{6}$ Vengerovskii A.I., Vaizova O.E., Plotnikova T.M. Akademik Nikolai Vasil'evich Vershinin. Tomsk, 2017.

7 Vengerovskii A.I. Evgeniia Mikhailovna Dumenova (k 100-letiiu so dnia rozhdeniia) // Biulleten' sibirskoi meditsiny. 2010. Iss. 6. P. 165-167.

8 Saratikov A. S., Krasnov E. A. Rodiola rozovaia (zolotoi koren'). Tomsk, 2004. P. 5. 
in part due to perseverance of its leader, Professor G. V. Krylov who ventured as high as 3000 meters above the sea level in the pine woods of Altai Mountains to finally be able to locate Rhodiola rosea 9 .

The scientific study of Rhodiola rosea started in Tomsk already in 1961 and continued for more than 30 years. Researchers faced a whole number of tasks that had to be completed before the drug could enter clinical practice. First, there were some pharmacognostic aspects to take care of - complete botanical description of the plant, the evaluation of its natural reserves and the possibility of its introduction and cultivation, chemical study of the different parts of the plant (especially the root) and their storage etc. Trials on animals or humans were deemed impossible prior to the completion of this introductory task.

Tomsk scientists used the methods of analytical chemistry to determine the chemical composition of the experimental drug, to forecast the biological activity of its components and to offer a preliminary estimate of its toxicity. The data that were received during this round of studies have very high value and in fact represent up to one third of the total amount of publications on Rhodiola rosea that were produced in Tomsk during the Soviet period.

The studies of physical and chemical qualities of the plant extract were carried out in the TMI laboratories by a large group of scientists, including Saratikov and Krasnov, the authors of the defining monograph on the "golden root"10. The Pharmacology Department clearly played the leading role in these studies, but other TMI departments also took part in the endeavor (especially the Department of the Technology of Medicinal Forms headed by Saratikov in 1954-1961) - as did a number of other research and medical institutions in the region ${ }^{11}$. While research was often conducted by several independent teams, their participants made sure to inform each other about the results of their studies and to keep sight of the broad picture by organizing numerous scientific conferences and publishing edited volumes on the subject.

First published results appeared already in 1961 when Tomsk scientists K.A.Sobolevskaia and V. G. Minaeva ${ }^{12}$ produced a description of the chemical composition of the plant's flowers. By 1968, there had been a whole range of published works on the biological properties of the plant ${ }^{13}$, including L.M. Khod'ko's doctoral thesis entitled

9 Saratikov A. S., Krasnov E. A. Rodiola rozovaia (zolotoi koren'). P. 5.

${ }^{10}$ Fominykh S. F., Nekrylov S. A., Gribovskii M. V., Mendrina G. I., Vengerovskii A. I., Novitskii V. V. Professora meditsinskogo fakul'teta Imperatorskogo (gosudarstvennogo) Tomskogo universiteta - Tomskogo meditsinskogo instituta - Sibirskogo gosudarstvennogo meditsinskogo universiteta (1878-2013): Biograficheskii slovar'. $2^{\text {nd }}$ ed. Tomsk, 2013. Vol. 1. P. 405-406.

${ }^{11}$ Not all experiments can be clearly attributed to a particular clinical or laboratory "base", yet there is evidence of a wide range of local institutions involved in the studies.

12 Sobolevskaia K. A., Minaeva V.G. K izucheniiu flory Altaia kak istochnika flavonovykh veshchestv // Izvestiia Sibirskogo otdeleniia AN SSSR. 1961. Iss. 4. P. 68-72.

${ }^{13}$ Khnykina L.A., Zotova M.I. K farmakognosticheskomu izucheniiu rodioly rozovoi // Aptechnoe delo. 1966. Iss. 6. P.34-38; Saratikov A. S., Aksenova R. A., Zotova M. I., Nekhoda M. F., Cherdyntsev S. G. K farmakologii zolotogo kornia // I Vsesoiuznyi s"ezd farmatsevtov: Materialy dokladov v sektsiiakh. Moscow, 1967. P. 66-67; Saratikov A. S., Krasnov E. A., Khnykina L. A., Duvidzon L. M. Vydelenie i khimicheskoe issledovanie individual'nykh biologicheski aktivnykh veshchestv iz rodioly rozovoi i chetyrekhlepestnoi // Izvestiia Sibirskogo otdeleniia AN SSSR. Seriia biologicheskikh i meditsinskikh nauk. 1967. Vol.5, iss. 1. P. 54-60; Saratikov A. S., Krasnov E. A., Khnykina L.A., Duvidzon L.M., Zotova M. I., Marina T. F., Nekhoda M.F., Aksenova R. A., Cherdyntsev S. G. Rhodiolosid, ein neues Glykosid aus Rhodiola rosea und seine pharmakologische Eigenschaften // Pharmazie. 1968. Vol.23, iss.7. P.302-305; Krasnov E. A., Veits L.A. 
"The Extraction of Biologically Active Substances and Rational Drugs from Rhodiola rosea" 14 .

In the mid-1960s, scientists started carrying out laboratory experiments on animals - facilitated by the presence of a large-scale vivarium on TMI's grounds since the mid-1930s ${ }^{15}$. These studies had their goal in determining the potential medicinal directions for applying the plant-based drug as well as establishing a preliminary estimate of its toxicity and safety (doses were established in the "experimental-theoretic" manner). Among those most involved in the study of Rhodiola rosea at the TMI between the 1960s and the 1980s, was T.F.Marina. Together with T.P. Prishchep, she conducted first experiments on the overall effect and toxicity of the drug on mice ${ }^{16}$. In doing so, the scientists used the roots of the plant that had been collected during Krylov's 1961 expedition to produce a $20 \%$ decoction and a $20 \%$ infusion (spirit-based). The experiments were of a deliberately comparative character as the extract of Rhodiola rosea was contrasted with those of ginseng, may chang and eleuterococcus. As a result of this comparison, "golden root" was proven to have the strongest effect. The scientists established the drug's toxicity level and described its influence on blood pressure, amplitude of heart contraction and breath stimulation in animals. However, their primary goal seemed to have been to determine the stimulating qualities of the drug which were to become the ultimate criterion of value for the forthcoming studies. Consequently, already in their first publication, Marina and Prishchep included the descriptions of two experiments with mice that demonstrated clear stimulating effect of the golden root.

Another scientist, M.I.Zotova, headed a research group which studied the influence of different drugs on stamina in mice using a method called after I. I. Brekhman ${ }^{17}$. More specifically, she compared Rhodiola rosea with eleuterococcus, at the time an already well-researched medicinal plant. The conditions of Zotova's experiment involved a moving pole that mice had to climb after being exposed to electricity at the bottom of the cage. The amount of time that the animal could stay on the pole was taken to be the reflection of its physical stamina. Comparing the efficiency of "optimal doses" of both drugs $(0,1 \mathrm{ml} /$ $20 \mathrm{~g}$ ) Zotova found that while eleuterococcus increased stamina in mice by a significant $74 \%$, Rhodiola rosea gave a whopping $233 \%$ increase ${ }^{18}$. In addition, the study showed the effects of the golden root on other physiological processes, including leukocytic reaction (which demonstrated the drug's effectiveness in protecting the organism from leukocytosis).

Notably, animal experiments continued after the start of human experiments and even after the registration of the drug by the Ministry of Health of the Soviet Union in 1975. TMI scientists conducted hundreds additional studies of Rhodiola rosea and its components and produced comprehensive descriptions of the biochemical mechanisms of

\footnotetext{
Issledovanie efirnogo masla rodioly rozovoi (Rhodiola rosea) // Stimuliatory tsentral'noi nervnoi sistemy. Tomsk, 1968. Vol. 2. P. 18-20.

${ }^{14}$ Khod'ko L. M. Vydelenie biologicheski aktivnykh veshchestv i poluchenie ratsional'nykh preparatov iz rodioly rozovoi: diss. ... kand. biol. nauk. Tomsk, 1968.

15 Gribovskii M. V. Organizatsiia nauchnykh issledovanii v Tomskom meditsinskom institute v 30-kh godakh XX veka // Biulleten' sibirskoi meditsiny. 2006. Issue 3. P. 128-132.

16 Marina T. F., Prishchep T. P. K farmakologii zolotogo kornia // Izvestiia SO AN SSSR. Iss. 4. P. 49-55.

17 Zotova M. I. Sravnitel'naia kharakteristika stimuliruiushchego i adaptogennogo deitsviia ekstraktov zolotogo kornia i eleuterokokka // Stimuliatory tsentral'noi nervnoi sistemy. Tomsk, 1966. P. 67-71.

${ }^{18}$ Ibid. P. 68.
} 
their stimulating and "adaptogenic" properties as well as their influence on cardiovascular, central nervous, endocrine and other systems. The results of experiments on animals were later extrapolated on humans, providing the necessary base for further stages of research.

Experiments on Humans. Since Rhodiola rosea had already been "tested" for safety by the generations of native Altaians, the scientists did not expect it to be dangerous for humans in reasonable dosage. Consequently, when Saratikov organized the first human experiments at the end of the 1960s, he recruited participants from volunteering students and faculty at the Institute. Clearly, from a contemporary perspective, this was not a purely "volunteer" study as it involved potential health risks yet did not take note of the existing power relations between a leader of the research group and his subordinates.

While there is a need for further research on the subject, there are at least some indications that these experiments might have contradicted the principles of voluntariness as described in the Nuremberg Code (1947) and the Declaration of Helsinki (1964). By the time Saratikov conducted his studies, these ethical standards had already been universally adopted and globally implemented to "humanize" biomedical research. The Nuremberg Code, for example, explicitly proclaimed "voluntary consent" of an individual to be "an absolutely necessary condition" for conducting experiments on humans. It further stipulated that the right to give (or to deny) consent should be free of violence, deception or other forms of coercion. Furthermore, the Declaration of Helsinki that was adopted by the World Medical Association (WMA) in 1964 explicitly prohibits the participation of students in biomedical experiments.

While it is widely considered to be a cornerstone document of contemporary human research ethics, the Declaration of Helsinki was not legally binding for the USSR. Nevertheless, at the time the Soviets also explored ethical dimensions of biomedical research and analyzed international standards, specifically noting the differences between "capitalist" and "socialist" approaches to science. Of particular interest here is Eduard A. Babaian and Oleg B. Utkin's 1982 book which highlighted the superiority of the Soviet system of clinical trials and specifically noted that "unlike in many capitalist countries, in the USSR the clinical study of new pharmaceuticals on healthy volunteers is not allowed"19. Partly, they described this restriction as a purely pragmatic one and put doubt on the comparability of results gained from studies of healthy volunteers and diagnosed patients (because of the "metabolic changes" in "diseased organisms") ${ }^{20}$.

However, Babaian and Utkin also criticized the (Western) understanding of "volunteers" from an ideological standpoint, noting specifically that in the "capitalist" world researchers often use "inmates, students, mentally and physically disabled people, i. e. all those who are in one way or another considered dependent" - the practice that the Soviet experts viewed as "unacceptable"21. They further criticized the concept of voluntary participation "in the world of profit [nazhiva] and capital" where people are forced "to sell their own health"22. At the same time, there was a certain leeway in Babaian and Utkin's description as in the USSR the study of medicine designed for use in healthy people (such as

19 Babayan E. A., Utkin O. B. Osnovnye polozheniia aprobatsii lekarstvennykh sredstv... P. 90.

20 Ibid. P.91.

21 Ibid. P. 90.

22 Ibid. P. 92. 
vaccines or repellents) could involve healthy research participants ${ }^{23}$. (Arguably, the TMI experiments with golden root could be included in this domain as the drug was primarily supposed to be used in healthy humans because of its "adaptogenic" qualities).

Clearly, many of the arguments made in the book were entangled in the highly ideological Cold War context. At the same time, they did point to a number of ethical and human rights issues that continued to plague Western (and specifically American) biomedical science well into the $20^{\text {th }}$ century. One of the most infamous examples of violating ethical norms while conducting biomedical research was the infamous Tuskegee Syphilis Study conducted in 1932-1972. The experiment proclaimed its goal the study of the "natural" course of syphilis and involved a large group of research participants who were denied their right to learn the diagnosis and receive treatment (even after the discovery of antibiotics) which resulted in medically sanctioned infection of families and relatives. Additionally problematic was the racial dimension of this experiment as the participants only included African Americans - a classic example of a vulnerable group of people as described in the Declaration of Helsinki.

According to the Declaration, vulnerable people (groups of people) carry a higher risk of abuse on behalf of the medical personnel, as for one reason or another they have more difficulties in defending themselves. For this reason, they have been more likely to become victims of unethical experiments. The Tuskegee Syphilis Study was not the only case of exploitation of vulnerable people in biomedical research. As several scholars have shown, the enlistment of "volunteers" from inmates or substance users was a common (if criticized) practice in the US until at least the mid-1970s ${ }^{24}$. Whether or not similar practices also took place in the USSR is hard to establish as the Soviet system was relatively more closed. In any case, as noted above, students and fellow researchers were commonly "used" as research participants at the TMI, and this practice could have generated ethical issues in regard to vulnerability and human rights.

In his book, Saratikov gives a detailed description of the methods that he used in his experiments and references many contemporary publications on the theory of medical experiment involving humans. For example, one experiment that he run involved a comparative study of Rhodiola rosea in a concentration test designed by V. Ia. Anfimov (underlining the letters called out by the test conductor in a $40 \times 40$ table). This test involved "poisoning" of students with a $40 \%$ ethanol solution to study the "adaptogenic" qualities of Rhodiola rosea ${ }^{25}$ - an effect that was convincingly demonstrated in the experiment as the group taking the drug produced consistently better results. Interestingly, in this experiment the researcher used placebo and "blinding" method that was quite innovative for that time (and, importantly, not officially adopted by the Soviets who were concerned about some of the ethical ramifications of "blinding"26).

${ }^{23}$ Babayan E. A., Utkin O. B. Osnovnye polozheniia aprobatsii lekarstvennykh sredstv... P. 92.

${ }^{24}$ Sun M. Inmates sue to keep research in prisons // Science. 1981. Vol.212, iss.4495. P.650-651; Stark L., Campbell N.D. Stowaways in the history of science: The case of simian virus 40 and clinical research on federal prisoners at the US National Institutes of Health, 1960 // Studies in History and Philosophy of Science Part C: Studies in History and Philosophy of Biological and Biomedical Sciences. 2014. Vol. 48. P. 218-230; Campbell N.D., Stark L. Making up "Vulnerable" People: Human Subjects and the Subjective Experience of Medical Experiment // Social History of Medicine. 2015. Vol.28, iss. 2. P. 825-848.

25 Saratikov A. S., Krasnov E. A. Rodiola rozovaia (zolotoi koren'). P. 94.

${ }^{26}$ See: Babayan E. A., Utkin O. B. Osnovnye polozheniia aprobatsii lekarstvennykh sredstv... P. 57. 
In a different experiment carried out in 1968, S. F. Tuzov conductued comparative trials of Rhodiola rosea and other known stimulants with a group of Tomsk athletes ${ }^{27}$. To gauge the participants' physical stamina, Tuzov used special cycling machine which allowed for precise measurement of the amount of energy spent when exercising. While short-distance tests did not show any significant differences, the longer endurance ones (designed to measure "the limit of performance capacity" [do predela utomliaemosti]) demonstrated a more pronounced effect of Rhodiola rosea as compared, for example, to eleuterococcus ( $9 \%$ vs $6 \%$ ). Even more indicative were the results of the so-called recovery tests which showed a $28 \%$ increase in the group which was given the experimental drug. Accordingly, the experiments showed that using Rhodiola rosea during severe and prolonged physical exercise resulted in a much faster recovery without influencing the quality of sleep. In the Cold War context, this observation was certainly of potential interest in various fields - from professional sports to military to space exploration - and the experiments were successfully continued by O. I. Dalinger (TMI's Physical Education Department).

Subsequent clinical trials of Rhodiola rosea were mostly carried out in several medical institutions in Tomsk. For example, in TMI's psychiatry clinic E. D. Krasik explored the possibility of treating astenic, neurotic, hypotonic and schizophrenic patients with Rhodiola rosea. Studies involved more than 400 patients with different mental health issues, including some healthy and "almost healthy" subjects who were "involved in intense intellectual labor". M. N. Mikhailova also conducted the study of the drug's effectiveness in treating insomnia. Numerous other ways of using the drug were conducted by the Tomsk physicians even after the drug was formally registered by the Soviet Ministry of Health in October 1975. For example, further experiments were carried out at the Mental Health Research Institute of the Tomsk branch of the Soviet Academy of Medical Sciences in 1981-1986. The medicinal properties of the plant were also studied in cases of hypotony (A. P. Fateeva, V.A.Smirnov), hearing problems (V.F. Oleinichenko), and amenorrhea (N.D. Gerasimova). In the context of Mikhail Gorbachev's anti-alcohol policy of the late 1980s, attempts were made to substitute the commonly used alcoholic tincture of Rhodiola rosea for the tablet form - with only limited success ${ }^{28}$.

Comparing Soviet and American Models of Drug Regulation. Tracing the history of clinical trials of Rhodiola rosea in Tomsk enables to study functioning of the Soviet system of pharmaceutical regulation on the ground and to situate it internationally. As was noted above, the most relevant comparison in the Cold War context is of course the American model that is: 1) well-studied; and 2) often perceived as the most developed and advanced. At the same time, it is important to note that the process of developing the regulatory system in the U.S. context was very difficult and at times - tragic. Almost every milestone was preceded by an incident involving numerous people dying or becoming severely disabled. This process was also characterized by a prolonged adversity between private pharmaceutical business (the so-called "Big Pharma") and progressive attempts to

27 Tuzov S.F. Sravnitel'naia kharakteristika deistviia nekotorykh stimuliatorov tsentral'noi nervnoi sistemy na myshechnuiu rabotosposobnost' cheloveka // Stimuliatory tsentral'noi nervnoi sistemy. Tomsk, 1968. Vol. 2. P. 156-161.

${ }^{28}$ Ekstrakt rodioly sukhoitabl.Zaiavochnaia, normativno-tekhnicheskaiai ekspertno-issledovatel'skaia dokumentatsiia // Rossiiskii gosudarstvennyi arkhiv nauchno-tekhnicheskoi dokumentatsii. F. 236. Op. 1-1. D. 2515. L. 19-20, 50-52, 86-88, 95-103, 112-123. 
establish a safe and efficient system for regulating the development, testing and sale of new drugs. The history of this regulation is usually subdivided into three main stages.

The first significant event took place in 1906 with the adoption of the Pure Food and Drug Act ${ }^{29}$ which obliged the pharmaceutical companies to include the correct information about the content of the drug on the label - a move which restricted the spread of toxic medicines. At the same time, the law had a certain compromising character and did not imply serious liability for the producer in most cases as the court had to prove that misinformation was deliberate. Nevertheless, the Act did make more difficult the sale of certain medications that were known to be dangerous. It also resulted in the creation of a special bureaucratic institution - the Food and Drug Administration (FDA).

The second defining moment in the history of pharmaceutical regulation in the US is commonly seen to have been the elixir sulfanilamide disaster in the late 1930s when more than a hundred people died after using the medicine. The government response to the tragedy culminated in the adoption of the Federal Food, Drug and Cosmetic $\mathrm{Act}^{30}$ which demanded that the producer carry out laboratory studies of drug safety and provide relevant instructions for every medicine.

Finally, the third milestone is connected with the disaster resulting from mass use of thalidomide, a sedative drug, in 1955-1962 ${ }^{31}$. The use of this drug by pregnant women led to various pathologies of fetal development resulting in early death or severe disability. The estimates of the number of victims in different countries are around tens of thousands of people, most of them in West Germany. The United States largely avoided the disaster due to the professional and principled position of Frances Oldham Kelsey, an FDA expert who refused to register thalidomide due to lack of evidence despite the unprecedented pressure from the producer. The ensuing public reaction (including support from President John Kennedy) led to the adoption of important amendments to the Federal Food, Drug and Cosmetic Act (known as Kefauver Harris Amendment). From now on, the producers were obliged to provide proof of both safety and effectiveness of new drugs that was to be based on clinical trials of these pharmaceuticals.

The comparison with the Soviet model shows that throughout the $20^{\text {th }}$ century the USSR was on a par with the US in terms of regulation and establishing drug safety and perhaps in certain respects even set the pace globally ${ }^{32}$. In the late Soviet period, however, both epistemological and ethical problems intensified. Soviet concerns over the use of randomized controlled trials and the practice of "blinding" led to the situation where biomedical knowledge was increasingly difficult to replicate in the laboratory, whereas the highly centralized and personalized character of scientific research in the USSR also gave room for potentially unethical treatment of research participants during drug development and testing. Clearly, this system could also produce extraordinary results while at the same time refraining from ethically questionable practices (particularly in moments of crisis, as evident from the Vershinin-Iablokov case or from the studies of polio vaccine

${ }^{29}$ Carpenter D. Reputation and power: organizational image and pharmaceutical regulation at the FDA. Princeton, 2010. P.75.

30 Ibid. P.73.

31 Ibid. P. 238.

32 For an international overview see: Hoboek B., Lie A. K. Less is More: Norwegian Drug Regulation, Antibiotic Policy, and the "Need Clause" // The Milbank Quarterly: A Multidisciplinary Journal of Population Health and Health Policy. 2019. Vol.97, iss. 3. P. 762-795. 
by M.P. Chumakov and A. A. Smorodintsev). However, by the end of the $20^{\text {th }}$ century such "paternalistic" research ethos was increasingly becoming obsolete.

Conclusion. Overall, between the 1960s and the early 1990s, more than 150 publications on Rhodiola rosea appeared in Soviet medical journals. It can be noted that such lengthy and comprehensive study of this medicinal plant was probably unnecessary and perhaps prolonged artificially, as many of the more potent drugs that were developed by the Soviets did not have this protracted cycle of clinical trials. In a way, the study of the "golden root" was meant to be not only a purely scientific endeavor but also became a local trademark and an educational vehicle for actively involving junior researchers (including students) and providing them with an opportunity to apply some of the skills they received during the period of their study.

After the collapse of the Soviet regime and the transition to market economy in the early 1990s, the number of publications on Rhodiola rosea dropped dramatically (even though some studies on the effects of the drug in cardiological, gastroenterological and oncological practice continued well into the post-Soviet period). However, there are some signs of renewed interest in the plant - as its diverse effects are being discovered both by global biomedical science ${ }^{33}$ and by local manufacturers of beauty products (as manifested by the recent launch of several "golden root"-based products by Natura Siberica, first Russian brand of organic cosmetics).

On a more general level, the studies of Rhodiola rosea in Tomsk in the late Soviet period can perhaps be characterized as quite modern by the contemporary standards. As has been noted above, the study included five consecutive phases: 1) experimental laboratory studies; 2) experiments on animals; 3) pre-clinical trials on healthy human volunteers; 4) clinical trials on a small group of patients; and 5) studies of a registered drug in different areas of medicine. Such an approach corresponded to the rules of "good practice" that were described as legal and ethical standards at the time. Nevertheless, it should be noted that further study of the Soviet regulatory system and "real-life" practices of drug testing in the USSR can also reveal ethically problematic issues in the treatment of research participants as well as unexpected divergences from the officially prescribed Soviet clinical trials practices.

\section{References}

Babayan E.A., Utkin O.B. Basic provisions of approbation of medicines in the USSR and foreign countries. Moscow, Meditsina Publ., 1982, 189 p. (In Russian)

Campbell N. D., Stark L. Making up "Vulnerable" People: Human Subjects and the Subjective Experience of Medical Experiment. Social History of Medicine, 2015, vol. 28, iss. 2, pp. 825-848.

Carpenter D. Reputation and power: organizational image and pharmaceutical regulation at the FDA. Princeton, Princeton University Press, 2010, 802 p.

Fominykh S. F., Nekrylov S. A., Gribovskii M. V., Mendrina G. I., Vengerovskii A. I., Novitskii V. V. Professors of the Medical Faculty of the Imperial (State) Tomsk University - Tomsk Medical Medical University Siberian State Medical University (1878-2013): Biographical Dictionary. $2^{\text {nd }}$ ed. Tomsk, Izdatel'stvo Tomskogo universiteta Publ., 2013, vol. 1, 488 p. (In Russian)

${ }^{33}$ See, e. g.: Mao Y., Li Y., Yao N. Simultaneous determination of salidroside and tyrosol in extracts of Rhodiola L. by microwave assisted extraction and high-performance liquid chromatography // Journal of Pharmaceutical and Biomedical Analysis. 2007. Vol.45, iss. 3. P. 510-515; Ishaque S., Shamseer L., Bukutu C., Vohra S. Rhodiola rosea for physical and mental fatigue: A systematic review // BMC Complementary and Alternative Medicine. 2012. Iss. 12. P. 70. 
Gribovskii M.V. Organization of scientific research at the Tomsk Medical Institute in the 30s of the XX century. Biulleten' sibirskoi meditsiny, 2006, iss. 3, pp. 128-132. (In Russian)

Hobæk B., Lie A. K. Less is More: Norwegian Drug Regulation, Antibiotic Policy, and the 'Need Clause'. The Milbank Quarterly: A Multidisciplinary Journal of Population Health and Health Policy, 2019, vol.97, iss. 3, pp. 762-795.

Ishaque S., Shamseer L., Bukutu C., Vohra S. Rhodiola rosea for physical and mental fatigue: A systematic review. BMC Complementary and Alternative Medicine. 2012, iss. 12, p. 70.

Karpov R.S. Memories of the teacher (to the 120th anniversary of the birth of Academician of the USSR Academy of Medical Sciences D. D. Yablokov). Biulleten' sibirskoi meditsiny, 2016, iss. 5, pp. 188-192. (In Russian)

Lepakhin V.K., Olefir Iu. V., Merkulov V.A., Buniatian N.D., Romanov B. K., Iavorskii A. N., Rychikhina E.M. The history of the creation and development of the control and licensing system in Russia (25 years since the creation of the first institution for expert evaluation of medical devices). Vedomosti Nauchnogo tsentra ekspertizy sredstv meditsinskogo primeneniia, 2016, iss. 2, pp. 3-10. (In Russian)

Mao Y., Li Y., Yao N. Simultaneous determination of salidroside and tyrosol in extracts of Rhodiola L. by microwave assisted extraction and high-performance liquid chromatography. Journal of Pharmaceutical and Biomedical Analysis, 2007, vol. 45, iss. 3, pp. 510-515

Saratikov A.S., Krasnov E. A. Rhodiola rosea (golden root). Tomsk, Izdatel'stvo Tomskogo universiteta Publ., 2004, 286 p. (In Russian)

Stark L., Campbell N.D. Stowaways in the history of science: The case of simian virus 40 and clinical research on federal prisoners at the US National Institutes of Health, 1960. Studies in History and Philosophy of Science Part C: Studies in History and Philosophy of Biological and Biomedical Sciences, 2014, vol. 48, pp. 218-230.

Sun M. Inmates sue to keep research in prisons. Science, 1981, vol.212, iss. 4495, pp. 650-651.

Vengerovskii A. I. Evgeniya Mikhailovna Dumenova (on the occasion of the $100^{\text {th }}$ anniversary of her birth). Biulleten' sibirskoi meditsiny, 2010, iss. 6, pp. 165-167. (In Russian)

Vengerovskii A. I. First Department of Pharmacology of Siberia. Eksperimental'naia i klinicheskaia farmakologiia, 2008, iss. 2, pp.60-64. (In Russian)

Vengerovskii A.I. The oldest department of pharmacology in Siberia (120 years from the date of opening). Biulleten' sibirskoi meditsiny, 2011, iss. 5, pp. 17-24. (In Russian)

Vengerovskii A. I., Vaizova O. E., Plotnikova T. M. Academician Nikolai Vasilievich Vershinin. Tomsk, Pechatnaia Manufaktura, 2017, 112 p. (In Russian)

Статья поступила в редакцию 2 февраля 2020 г. Рекомендована в печать 8 июня 2020 г.

Received: February 2, 2020 Accepted: June 8, 2020 